\title{
EFFECT OF WATER AMOUNT ADDED TO EL-SEBAY MODIFIED TRAP IN SANDY SOIL ON THE BEHAVIORAL ACTIVITY OF PSAMMOTERMES HYBOSTOMA, DESNEUX
}

\author{
EI-BASSIOUNY, A. R. \\ Plant Protection Research Institute, ARC, Dokki, Giza \\ (Manuscript received 14 January 2015)
}

\begin{abstract}
$\mathrm{E}$ xperiments were conducted in light sandy soil in Ismailia region to study effect of moisture amount added to ElSebay-modified trap on activity of sand termite Psammotermes hybostoma (Desn.) during 2014. The obtained results average revealed that, $500 \mathrm{ml}$ water/trap gave the highest activities of termite, which were (27211.6 individuals, $4123.94 \mathrm{gm}$ and $1004.56 \mathrm{gm}$ ) for termite attraction, soil translocation and food consumption respectively. This rate of moisture is considered more appropriate for El-Sebay-modified trap. The second of $250 \mathrm{ml}$ water/trap, recorded (22147.0 individuals, $3106.36 \mathrm{gm}$ and 833.46 $\mathrm{gm}$ ) for the three tested aspects, respectively. But using $1000 \mathrm{ml}$ water/trap caused the least activity (16967.4 individuals, 2657.79 $\mathrm{gm}$ and $752.72 \mathrm{gm}$ ). Increase of added water amount caused rotting and trap blockage and be unattractive to the insect. The temperature degrees and rain were effective on termite attraction and seasonal activities (soil translocation and food consumption). Data in statistical analysis detected not significant for the tested factors and inspections. It could be recommended, using of $500 \mathrm{ml}$ water/trap added to El-Sebay-modified trap gave the best function with the variable climates in light sandy soil.

Key Words: El-Sebay-modified trap; corrugated card-board; $P$. hybostoma; water quantity; attraction; consumption; translocation.
\end{abstract}

\section{INTRODUCTION}

A subterranean termite is one of the most destructive insect which causes a severe damage to buildings and crops all over the world, especially in rainy regions. Surface and subsurface activity of subterranean termites are just limited and depending on moisture content. So, surface activity (termite abundance) increased during winter and autumn seasons with decrement in subsurface activity (consumption and translocation), but it increment in summer season, with the decrement in population density, (El-Bassiouny 2001). Termite is easily affected by soil properties, (moisture, temperatures, soil texture, as well as chemical and physical components). Termites live in tunnels and can be able to adapt in a wide range of environments (temperatures and relative humidity). Subterranean termites can be able to live in the most of soil types (sandy silt, sandy clay, sandy loam and loamy 
clay), and are found in the arid and semi-arid region, (El-Bassiouny et al 2009). Some studies were conducted to study effect of moisture content on termite activity, Said (1979); Abou-Ghadir\&Khalifa (1982); Khalifa (1982); Morsy et al. (1982); AbdelWahab et al. (1983); Rizk et al. (1985); Salman et al. (1987); Evans (2003); Su \& Puche (2003); Green et al. (2005); McManamy et al. (2008) and Gautam\&Henderson (2011 a,b).

The present work was conducted to study variation of monthly activities, (attraction, translocation and consumption) of sand termite Psammotermes hybostoma (Desneux), at different water amounts added to El-Sebay-modified trap under field conditions during 2014 year at Ismailia region.

\section{MATERIALS AND METHODS}

\section{Used Trap:}

El-Sebay-modified trap (Fig., 1), which consists of corrugated-card wrapped in a roll shape, 7-10 cm in diameter and $12 \mathrm{~cm}$ in length, covered with polyethylene sheath except 1-2 cm at the end position fixed with rubber band, (El-Sebay 1991), was used.

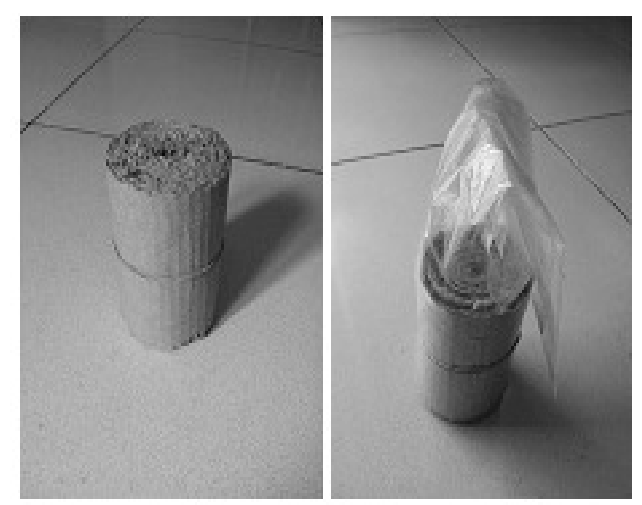

Fig. (1), El-Sebay-modified trap

\section{Soil Texture Analysis:}

Five soil samples were randomly taken from different places of infested area (Agric. Res. Station Ezz El-Deen Region, Ismailia Governorate) at depths of 30-60 cm in tested location and mixed together. Samples were sent to Soil Department at ElMansoura University for physical analysis (Table, 1). 
Table (1). Soil texture of five samples collected from infested area at depth $30-60 \mathrm{~cm}$

\begin{tabular}{|c|c|c|c|c|}
\hline Area & \multicolumn{3}{|c|}{ components } & \multirow{2}{*}{$\begin{array}{c}\text { Soil } \\
\text { texture }\end{array}$} \\
\hline \multirow{2}{*}{ Agric. Res. Station Ezz El-Deen Region, Ismailia Gov. } & Sand \% & Silt \% & Clay \% & \\
\hline & 88.16 & 09.05 & 0.02 & $\begin{array}{c}\text { Sandy } \\
\text { silt }\end{array}$ \\
\hline
\end{tabular}

\section{Field Work:}

Traps were prepared in Termite Laboratory, Plant Protection Research Institute (PPRI), Dokki, Giza. Traps were dried in an electrical oven at $105 \mathrm{C}^{\circ}$ for 24 hours until the weight was stable, Then, about 50 gram weight of trap type were used monthly to assess food consumption and soil translocation. Traps were transferred to Agric. Res. Station, Ezz El-Deen region, Ismailia governorate, which is characterized by light sandy soil. All sources of cellulose on soil surface were removed away. 100 traps were distributed in the tested area which occupied $400 \mathrm{~m}^{2}$ aligned to 5 column and 20 rows, with $2 \mathrm{~m}^{2}$ distance between adjacent traps (each trap subtended an area of $4 \mathrm{~m}^{2}$ ) in $1 / 12 / 2013$, to determine 10 infested positions to beginning test in $1 / 1 / 2014$, this means that, the treatments were replicated 10 times, taking into account the presence of distances between the locations of colonies tested for nonoverlapping colonies and accuracy of the results, Bodin 1975, in Texas, USA, mentioned that population density of attracted termite determined according to colony size, and surface to subsurface proportion of termites (1:114). Dry traps as a control were buried in colony center and other traps contained the tested moisture levels were placed in the form of a circular at equal distances from the center of the colony (1m) for each tested position (10 positions) Fig, (2). The tested water contents were 250, 500 and $1000 \mathrm{ml} /$ trap. The tested water amounts were added to traps, then, traps were buried in the ground at $15 \mathrm{~cm}$ depth. Each trap was marked and occupied the same position through investigation period. Traps were renewed monthly and examined in laboratory at Termite Research Unit, to estimate; number of attracted termites, food consumption losses and rate of soil translocation.

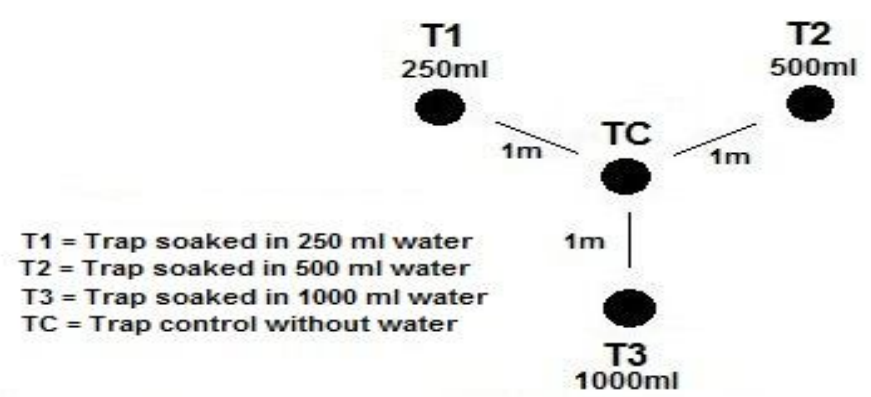

Fig. (2): Distribution of tested traps around colony center 


\section{Laboratory Work:}

In laboratory, each trap was inspecting and cached individuals were separated by small brush to record population density of termites. Constructed soils (translocated soil) were collected from each trap, the collected soil were dried at $\left(105^{\circ} \mathrm{C}\right)$ for 24 hours, then weighted. After removing insects and soil, the infested traps were also dried on $\left(105^{\circ} \mathrm{C}\right)$ in oven for 24 hours to determine the food consumption (Fig., 3). Data were recorded monthly for each trap.

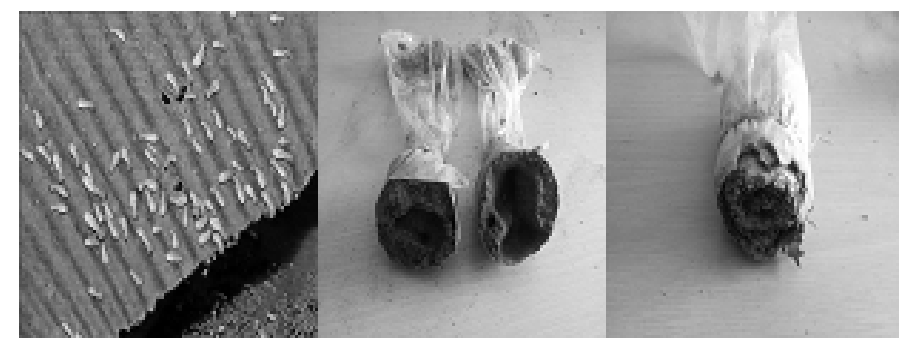

Fig. (3): Attracted termites, translocated soil and food consumption

Food consumption (Actual weight of consumed trap/gm) was calculated according to the following;

$$
\begin{aligned}
& \qquad \text { Fc = Twb - Twa } \\
& \text { FC = Food Consumption }(\mathrm{gm}) \\
& \text { TWb }=\text { Trap Weight before }(\mathrm{gm}) \\
& \text { TWa }=\text { Trap Weight after }(\mathrm{gm})
\end{aligned}
$$

\section{Climate Obtained Source:}

Data of climate (temperatures and rain $/ \mathrm{m}^{3}$ ) were obtained from Central Lab. of Agricultural Climate, Agric. Res. Center, Dokki, Giza, Egypt. Data were calculated as mean during 2014 year.

\section{Statistical Analysis:}

Simple correlation "r" used for the tested factors of P. hybostoma, and data were statistically calculated according to Proc ANOVA in SAS (SAS Institute, 1988).

\section{RESULTS AND DISCUSSION}

Soil moisture considered the major important factor for termite activities. The present work could help to give a knowledge about suitable water amount (250, 500 and $1000 \mathrm{ml} /$ trap) added to El-Sebay trap which used to study termite activities in the field at Ismailia region during 2014. 


\section{1- Termite Attraction:}

Data in Table (2), show that, the average of total numbers for termites attracted to 10 traps contained water amount of $250 \mathrm{ml}$ water/trap were 1900.6, 2073.2, 2001.0, 2500.9, 1001.7, 1310.0, 1270.3, 1400.0, 2010.1, 2100.5, 2508.0 and 2070.7 individuals, during Jan., Feb., Mar., Apr., May, June, July, Aug, Sept., Oct., Nov. and Dec. respectively, with total numbers of (22147.0 termites/year). The termites attracted to traps treated with $500 \mathrm{ml}$ water/trap, were, 2507.2, 2000.0, 3012.4, 1987.1, 2010.0, 1150.0, 0974.2, 1720.6, 1530.0, 2308.1, 1900.0 and 6112.0 individuals, during the same months of 2014, respectively, with total numbers of (27211.6 termites/year). While the traps contained water amount $1000 \mathrm{ml}$ water/trap, collected, 1000.0, 1522.0, 1204.7, 1332.8, 2100.3, 1305.1, 1030.0, 1011.4, 2000.0, 1411.1, 2000.0 and 1050.0, during Jan., Feb., Mar., Apr., May, June, July, Aug, Sept., Oct., Nov. and Dec. respectively, the total was (16967.4 termites/year).

As shown in Table (2) and Fig. (4), the highest percentages of collected termites (11.32, 22.46 and 12. $37 \%$ ) were obtained at 250, 500 and $1000 \mathrm{ml}$ water/trap in Nov., Dec., and May, respectively. The highest grand total of attracted termites was recorded in traps soaked in $500 \mathrm{ml}$ water/each, (Fig; 5).

Numbers of termite fluctuated during the year seasons, and data clarified the attracted termite to the traps treated with $250 \mathrm{ml} /$ trap, were the lower in summer season, counted 1001.7, 1310.0, 1270.3 and 1400.0 individuals in May, June, July and Aug., when the mean temperature were high 35.24, 35.72, 34.27 and $32.89{ }^{\circ} \mathrm{C}$ respectively and the mean rain were zero, this means the temperature degrees increasing and the rain are not found in this month's caused drying traps follow decreasing of attracted termites. In the same trend the traps treated with $500 \mathrm{ml}$ showed that, the attracted termites were lower at this period counted, 1150.0, 0974.2, 1720.6 and 1530.0 individuals during months June, July, Aug. and Sept. respectively when the mean temperature were high, 35.72, 34.27, 32.89 and $30.30^{\circ} \mathrm{C}$ and the mean rain were zero. Also, at the rate of tested water $1000 \mathrm{ml} / \mathrm{trap}$, the results were $1305.1,1030.0,1011.4$ and 2000.0 individuals in summer season June, July, Aug. and Sept., respectively when the mean temperature were 35.72, 34.27, 32.89 and $30.30{ }^{\circ} \mathrm{C}$ and the rain were zero. At all treatment the catching numbers increasing gradually in the autumn and winter seasons, data at the $1^{\text {st }}$ tested water $250 \mathrm{ml} /$ trap represented 2010.1, 2100.5, 2508.0, 2070.7, 1900.6, 2073.2, 2001.0 and 2500.9 individuals during Sept., Oct., Nov. Dec., Jan., Feb., Mar., and Apr., respectively, when the mean temperature were low represented 30.30, 25.12, 20.03, 18.6, 19.27, 23.24, 27.61 and $32.25^{\circ} \mathrm{C}$ and the rain were abundance, counted 0.0 , 26.8, 196.7, 201.3, 153.2, 109.7, 77.2 and $2.5 \mathrm{~m}^{3} / \mathrm{insh}^{2}$. At the $2^{\text {nd }}$ tested water 500 $\mathrm{ml} /$ trap, data of attraction increased in autumn represented 1720.6, 1530.0, 2308.1, 1900.0, 6112.0, 2507.2, 2000.0 and 3012.4 individuals during Aug., Sept., Oct., Nov. Dec., Jan., Feb., and Mar., respectively, when the mean temperature were low represented $32.89,30.30,25.12,20.03,18.6,19.27,23.24$ and $27.61^{\circ} \mathrm{C}$ and the rain 
were abundance, counted 0.0, 0.0, 26.8, 196.7, 201.3, 153.2, 109.7 and 77.2 $\mathrm{m}^{3} / \mathrm{insh}^{2}$. At $3^{\text {rd }}$ tested water $1000 \mathrm{ml} /$ trap data of attracted termites were increased in autumn and winter season, represented 2000.0, 1411.1, 2000.0, 1050.0, 1000.0, 1522.0, 1204.7, and 1332.8 individuals during Sept., Oct., Nov. Dec., Jan., Feb., Mar., and April respectively, when the mean temperature were low represented 30.30, $25.12,20.03,18.6,19.27,23.24,27.61$ and $32.25^{\circ} \mathrm{C}$ and the rain were abundance, counted $0.0,26.8,196.7,201.3,153.2,109.7,77.2$ and $2.5 \mathrm{~m}^{3} /$ insh $^{2}$.

On the other hand the preference and non preference of water rate added to El-Sebay trap were clarified throughout data in table (2), which resulted, that, the total of attracted termite were highly rate and appropriate in tested water $500 \mathrm{ml} /$ trap followed by tested water $250 \mathrm{ml} /$ trap, while the tested water $1000 \mathrm{ml} /$ trap were the lower in termite attraction.

\section{2- Soil Translocation:}

Data in Table (2) and Fig. (6), indicate that the average of soil translocation (gm) collected from 10 El-Sebay modified traps, contained $250 \mathrm{ml}$ water/trap, were 200.00, 138.22, 302.01, 295.33, 350.09, 200.00, 322.10, 157.40, 165.60, 400.00, 290.99 and 284.62 gm in Jan., Feb., Mar., Apr., May, June, July, Aug, Sept., Oct., Nov. and Dec. 2014 respectively, with the total (3106.36 gm/year). On the other hand, soil translocated by traps soaked in $500 \mathrm{ml}$ water/trap, were 450.20, 350.15, $390.00,324.16,388.99,211.02,113.50,299.22,264.05,444.00,316.12$ and 572.53, during the twelve successive months of 2014, respectively, the total were (4123.94 $\mathrm{gm} /$ year). While trap contained $1000 \mathrm{ml}$ water/trap, gave translocated soil of, 214.00, 150.17, 300.02, 150.55, 200.00, 113.09, 197.60, 211.72, 200.05, 323.23, 297.24 and 300.12 gm during Jan., Feb., Mar., Apr., May, June, July, Aug, Sept., Oct., Nov. and Dec. respectively, and the total were ( $2657.79 \mathrm{gm} /$ year).

The highest percentage of soil translocation (13.88\%) was shown during ultimate month of 2014 with traps contained $500 \mathrm{ml}$ water/trap, but in case of traps soaked in 250 and $1000 \mathrm{ml}$ water/trap, the highest percentages of translocated soils were nearly equal (12.87 and $12.16 \%$, respectively) which were investigated in Oct., of 2014 respectively, (Table, 2). The lowest amount of translocated soil was (2657.79 $\mathrm{gm} /$ year) was recorded with traps contained $1000 \mathrm{ml}$ water/trap, whereas the highest one (4123.94 gm/year) was shown with traps of $500 \mathrm{ml}$ water/trap, (Fig., 7).

Soil transmission average fluctuated during the year seasons, and data showed Soil transmitted weight/gm to the traps treated with $250 \mathrm{ml} /$ trap, increased in summer and autumn seasons, counted 350.09 and $322.10 \mathrm{gm}$ in May and July (in summer) respectively, when the mean temperature were 35.24 and $34.27^{\circ} \mathrm{C}$ and the mean rain were zero, while the highly rate were $400.00 \mathrm{gm}$ during Oct., (in autumn) with moderately range of soil temperature and rain $25.12{ }^{\circ} \mathrm{C}$ and $26.8 \mathrm{~m}^{3} / \mathrm{inch}^{2}$ respectively. At the tested water $500 \mathrm{ml} / \mathrm{trap}$, data resulted, the highly rate of translocated occurred in Dec., and Jan., represented 572.53 and $450.20 \mathrm{gm}$ respectively, with mean temperature $\left(18.6 \& 19.27^{\circ} \mathrm{C}\right)$ and mean rain 201.3 and 153.2 
$\mathrm{m}^{3} /$ inch $^{2}$. While data were highly rate of translocated occurred in Oct., represented $323.23 \mathrm{gm}$ followed by $300.12 \mathrm{gm}$ during Dec., with mean temperature (25.12\&18.6 ${ }^{\circ} \mathrm{C}$ respectively) and mean rain 26.8 and $201.3 \mathrm{~m}^{3} / \mathrm{inch}^{2}$ in use of tested water rate1000 ml/trap.

\section{3- Food Consumption:}

Data in Table (2) and Fig. (8), show termite food consumption in the tested traps of $250 \mathrm{ml}$ water/trap, 076.00, 084.33, 067.10, 072.03, 058.00, 061.22, 047.70, 066.05, 064.00, 077.41, 081.61 and $078.01 \mathrm{gm}$, that was investigated in Jan., Feb., Mar., Apr., May, June, July, Aug, Sept., Oct., Nov. and Dec. of 2014, respectively with total $(833.46 \mathrm{gm} /$ year). The corresponding food consumption in traps contained 500 $\mathrm{ml}$ water/trap, recorded 086.06, 093.30, 097.11, 087.00, 068.09, 081.01, 054.12, 086.17, 090.00, 091.55, 072.14 and 098.01, during 2014, respectively, with total (1004.56 gm/year). While traps contained $1000 \mathrm{ml}$ water/trap, showed food consumption of, 055.43, 064.12, 050.01, 062.10, 098.97, 056.11, 068.05, 041.00, 055.81, 057.12, 079.71 and 064.29 gm in Jan., Feb., Mar., Apr., May, June, July, Aug, Sept., Oct., Nov. and Dec. respectively, the total were (752.72 gm/year).

Data in Table (2) and Fig. (9), reveal that, the highest total amount of food consumption (1004.56 gm/year) was investigated in traps contained $500 \mathrm{ml}$ water/trap, whereas, the lowest amount $(752.72 \mathrm{gm})$ was recorded in traps of 1000 $\mathrm{ml}$ water/trap.

The average of consumption were fluctuated during the year seasons, and data resulted that the food consumption weight/gm from the traps treated with 250 $\mathrm{ml} /$ trap, increased in autumn and winter seasons, counted 077.41, 081.61, 078.01, 076.00 and $084.33 \mathrm{gm}$ in Oct., Nov., Dec., Jan., and Feb., respectively, when the mean temperature were $25.12,20.03,18.6,19.27$ and $23.24^{\circ} \mathrm{C}$ and the mean rain were $26.8,196.7,201.3,153.2$ and $109.7 \mathrm{~m}^{3} / \mathrm{inch}^{2}$, while the highly rate were 084.33 gm occurred during Feb., with moderately range of soil temperature and rain counted $23.24{ }^{\circ} \mathrm{C}$ and $109.7 \mathrm{~m}^{3} / \mathrm{inch}^{2}$ respectively. At the tested water $500 \mathrm{ml} / \mathrm{trap}$, data resulted, the highly rate of consumed traps in Dec., and March represented 098.01 and $097.11 \mathrm{gm}$ respectively, with mean temperature $\left(18.6827 .61^{\circ} \mathrm{C}\right)$ and mean rain 201.3 and $77.2 \mathrm{~m}^{3} / \mathrm{inch}^{2}$. While data were highly rate of translocated occurred when use of tested water rate1000 ml/trap occurred in May represented $098.97 \mathrm{gm}$ followed by $079.71 \mathrm{gm}$ during Nov., with mean temperature $\left(20.03 \& 35.24{ }^{\circ} \mathrm{C}\right.$ respectively) and mean rain 196.7 and $0.0 \mathrm{~m}^{3} /$ inch $^{2}$.

Data in total, revealed that, the preference and non preference of water amount added to El-Sebay-modified trap were clarified in table (2), which resulted, that, the total average of termite attraction, soil translocation and food consumption were highly rate in tested water $500 \mathrm{ml} /$ trap followed by tested water $250 \mathrm{ml} /$ trap, while the tested water $1000 \mathrm{ml} /$ trap were the lower in termite attraction. 
Table (2). Monthly average of attracted termite, soil translocation (gm) and food consumption (gm) of $P$. hybostoma (Desn.) in year 2014 using three levels of water added to El-Sebay trap.

\begin{tabular}{|c|c|c|c|c|c|c|c|c|}
\hline \multirow{2}{*}{ Months } & \multicolumn{6}{|c|}{ Traps treated with $250 \mathrm{ml}$ water } & \multirow{2}{*}{$\begin{array}{c}\text { Mean } \\
\text { Temp. }{ }^{\circ} \mathrm{C}\end{array}$} & \multirow{2}{*}{$\begin{array}{c}\text { Rain } \\
\mathrm{m}^{3} / \text { inch }^{2}\end{array}$} \\
\hline & A.T. & $\%$ & S.T. & $\%$ & F.C. & $\%$ & & \\
\hline Jan. & 1900.6 & 08.58 & 200.00 & 06.43 & 076.00 & 09.11 & 19.27 & 153.2 \\
\hline Feb. & 2073.2 & 09.36 & 138.22 & 04.44 & 084.33 & 10.11 & 23.24 & 109.7 \\
\hline Mar. & 2001.0 & 09.03 & 302.01 & 09.72 & 067.10 & 08.05 & 27.61 & 77.2 \\
\hline Apr. & 2500.9 & 11.29 & 295.33 & 09.50 & 072.03 & 08.64 & 32.25 & 02.5 \\
\hline May & 1001.7 & 04.52 & 350.09 & 11.27 & 058.00 & 06.95 & 35.24 & 0.00 \\
\hline June & 1310.0 & 05.91 & 200.00 & 06.43 & 061.22 & 07.34 & 35.72 & 0.00 \\
\hline July & 1270.3 & 05.73 & 322.10 & 10.36 & 047.70 & 05.72 & 34.27 & 0.00 \\
\hline Aug. & 1400.0 & 06.32 & 157.40 & 05.06 & 066.05 & 07.92 & 32.89 & 0.00 \\
\hline Sep. & 2010.1 & 09.07 & 165.60 & 05.33 & 064.00 & 07.67 & 30.30 & 0.00 \\
\hline Oct. & 2100.5 & 09.48 & 400.00 & 12.87 & 077.41 & 09.28 & 25.12 & 26.8 \\
\hline Nov. & 2508.0 & 11.32 & 290.99 & 09.36 & 081.61 & 09.79 & 20.03 & 196.7 \\
\hline Dec. & 2070.7 & 09.34 & 284.62 & 09.16 & 078.01 & 09.35 & 18.6 & 201.3 \\
\hline \multirow[t]{2}{*}{ Total } & 22147.0 & & 3106.36 & & 833.46 & & & \\
\hline & \multicolumn{6}{|c|}{ Traps treated with $500 \mathrm{ml}$ water } & & \\
\hline Jan. & 2507.2 & 9.21 & 450.20 & 10.91 & 086.06 & 8.56 & 19.27 & 153.2 \\
\hline Feb. & 2000.0 & 7.34 & 350.15 & 08.49 & 093.30 & 9.28 & 23.24 & 109.7 \\
\hline Mar. & 3012.4 & 11.07 & 390.00 & 09.45 & 097.11 & 9.66 & 27.61 & 77.2 \\
\hline Apr. & 1987.1 & 7.30 & 324.16 & 07.86 & 087.00 & 8.66 & 32.25 & 02.5 \\
\hline May & 2010.0 & 7.38 & 388.99 & 09.43 & 068.09 & 6.77 & 35.24 & 0.00 \\
\hline June & 1150.0 & 4.22 & 211.02 & 05.11 & 081.01 & 8.06 & 35.72 & 0.00 \\
\hline July & 0974.2 & 3.58 & 113.50 & 02.75 & 054.12 & 5.38 & 34.27 & 0.00 \\
\hline Aug. & 1720.6 & 6.32 & 299.22 & 07.25 & 086.17 & 8.57 & 32.89 & 0.00 \\
\hline Sep. & 1530.0 & 5.62 & 264.05 & 06.40 & 090.00 & 8.95 & 30.30 & 0.00 \\
\hline Oct. & 2308.1 & 8.48 & 444.00 & 10.76 & 091.55 & 9.11 & 25.12 & 26.8 \\
\hline Nov. & 1900.0 & 6.98 & 316.12 & 07.66 & 072.14 & 7.18 & 20.03 & 196.7 \\
\hline Dec. & 6112.0 & 22.46 & 572.53 & 13.88 & 098.01 & 9.75 & 18.6 & 201.3 \\
\hline \multirow[t]{2}{*}{ Total } & 27211.6 & & 4123.94 & & 1004.56 & & & \\
\hline & \multicolumn{6}{|c|}{ Traps treated with $1000 \mathrm{ml}$ water } & & \\
\hline Jan. & 1000.0 & 5.89 & 214.00 & 08.05 & 055.43 & 7.36 & 19.27 & 153.2 \\
\hline Feb. & 1522.0 & 8.97 & 150.17 & 05.65 & 064.12 & 8.51 & 23.24 & 109.7 \\
\hline Mar. & 1204.7 & 7.10 & 300.02 & 11.28 & 050.01 & 6.64 & 27.61 & 77.2 \\
\hline Apr. & 1332.8 & 7.85 & 150.55 & 05.66 & 062.10 & 8.25 & 32.25 & 02.5 \\
\hline May & 2100.3 & 12.37 & 200.00 & 07.52 & 098.97 & 13.14 & 35.24 & 0.00 \\
\hline June & 1305.1 & 7.69 & 113.09 & 04.25 & 056.11 & 7.45 & 35.72 & 0.00 \\
\hline July & 1030.0 & 6.07 & 197.60 & 07.43 & 068.05 & 9.04 & 34.27 & 0.00 \\
\hline Aug. & 1011.4 & 5.96 & 211.72 & 07.96 & 041.00 & 5.44 & 32.89 & 0.00 \\
\hline Sep. & 2000.0 & 11.78 & 200.05 & 07.52 & 055.81 & 7.41 & 30.30 & 0.00 \\
\hline Oct. & 1411.1 & 8.31 & 323.23 & 12.16 & 057.12 & 7.58 & 25.12 & 26.8 \\
\hline Nov. & 2000.0 & 11.78 & 297.24 & 11.18 & 079.71 & 10.58 & 20.03 & 196.7 \\
\hline Dec. & 1050.0 & 6.18 & 300.12 & 11.29 & 064.29 & 8.54 & 18.6 & 201.3 \\
\hline Total & 16967.4 & & 2657.79 & & 752.72 & & & \\
\hline
\end{tabular}

A.T. $=$ Attracted Termites

S.T. = Soil Translocation

F.C. $=$ Food Consumption 


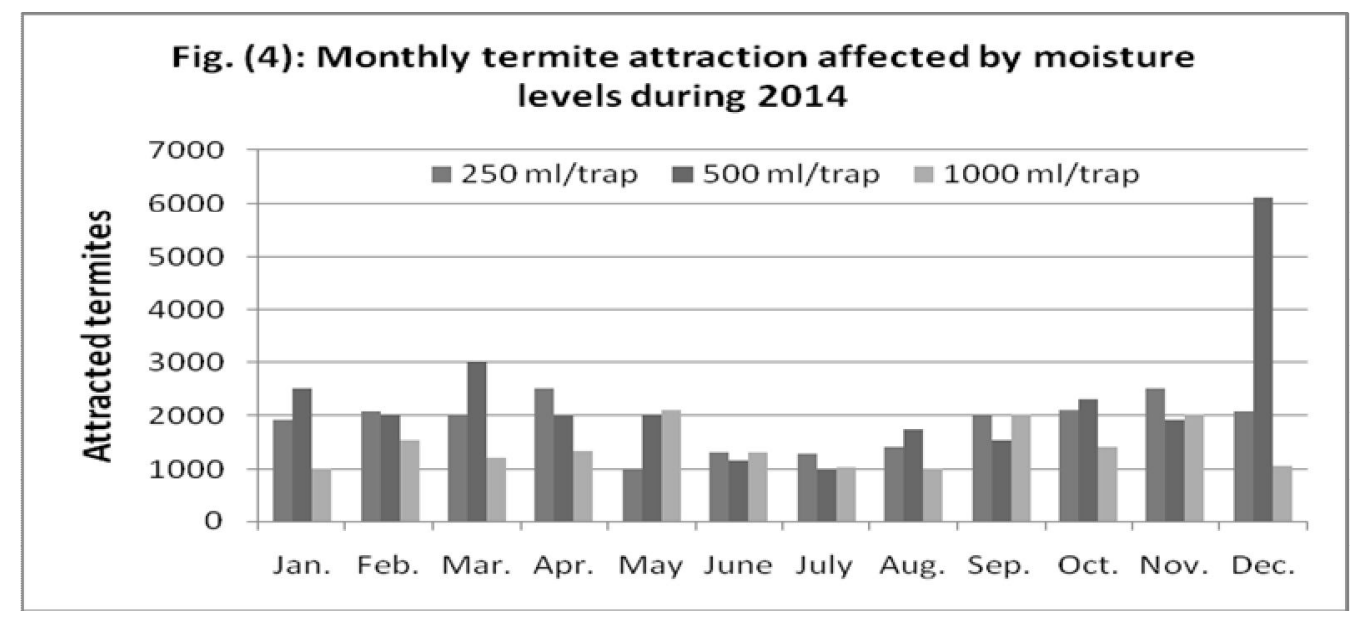

Fig. (5): Total collected termites affected by moisture levels during 2014

$$
\begin{aligned}
& -250 \mathrm{ml} / \text { trap } \\
& -500 \mathrm{ml} / \text { trap } \\
& 1000 \mathrm{ml} / \text { trap }
\end{aligned}
$$
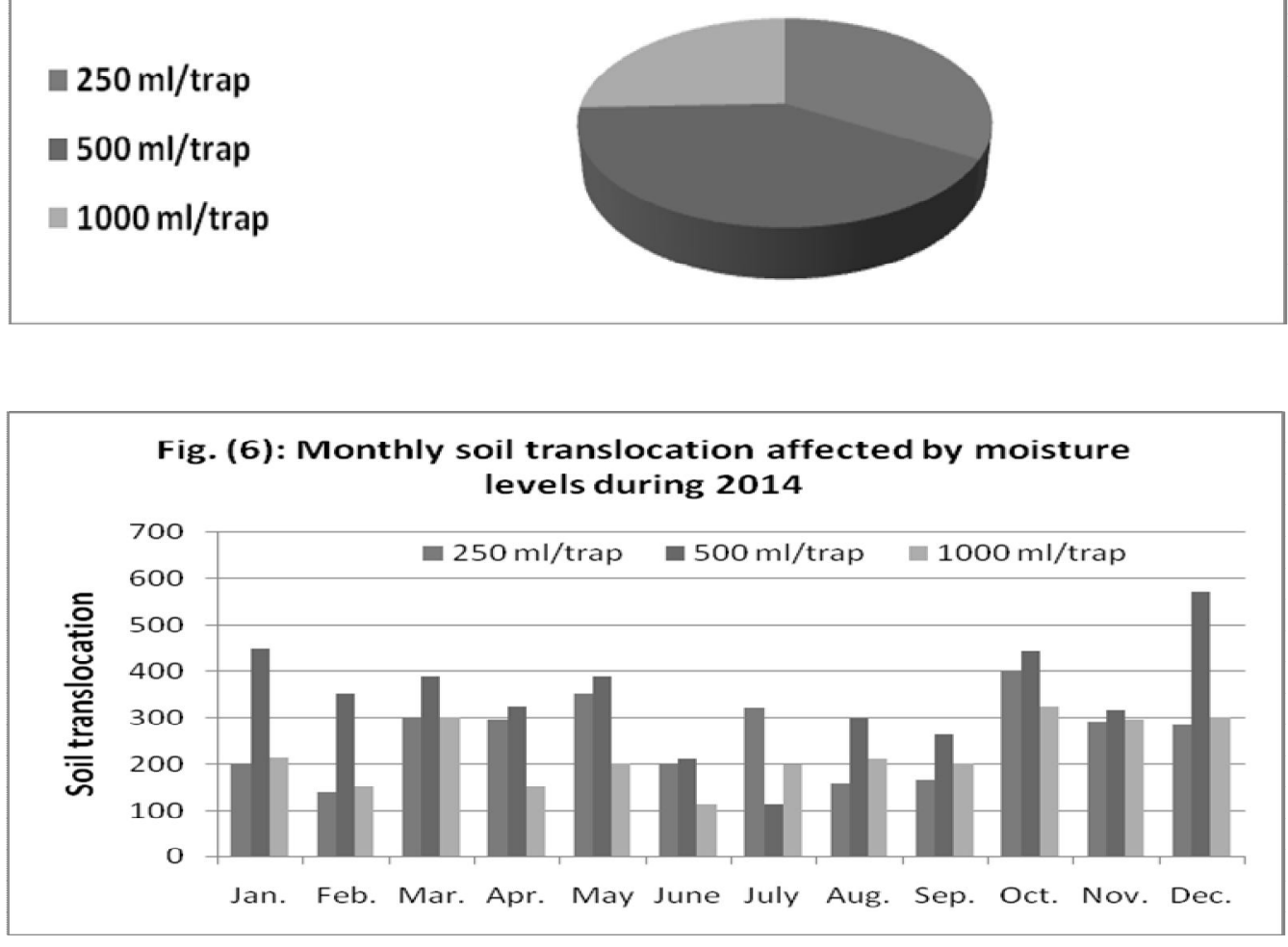

Fig. (7): Total soil translocation affected by moisture levels during 2014

$=250 \mathrm{ml} / \mathrm{trap}$

- $500 \mathrm{ml} / \mathrm{trap}$

$\square 1000 \mathrm{ml} /$ trap

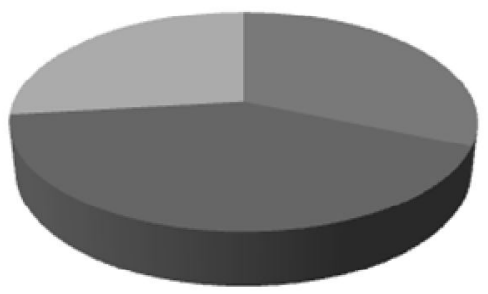



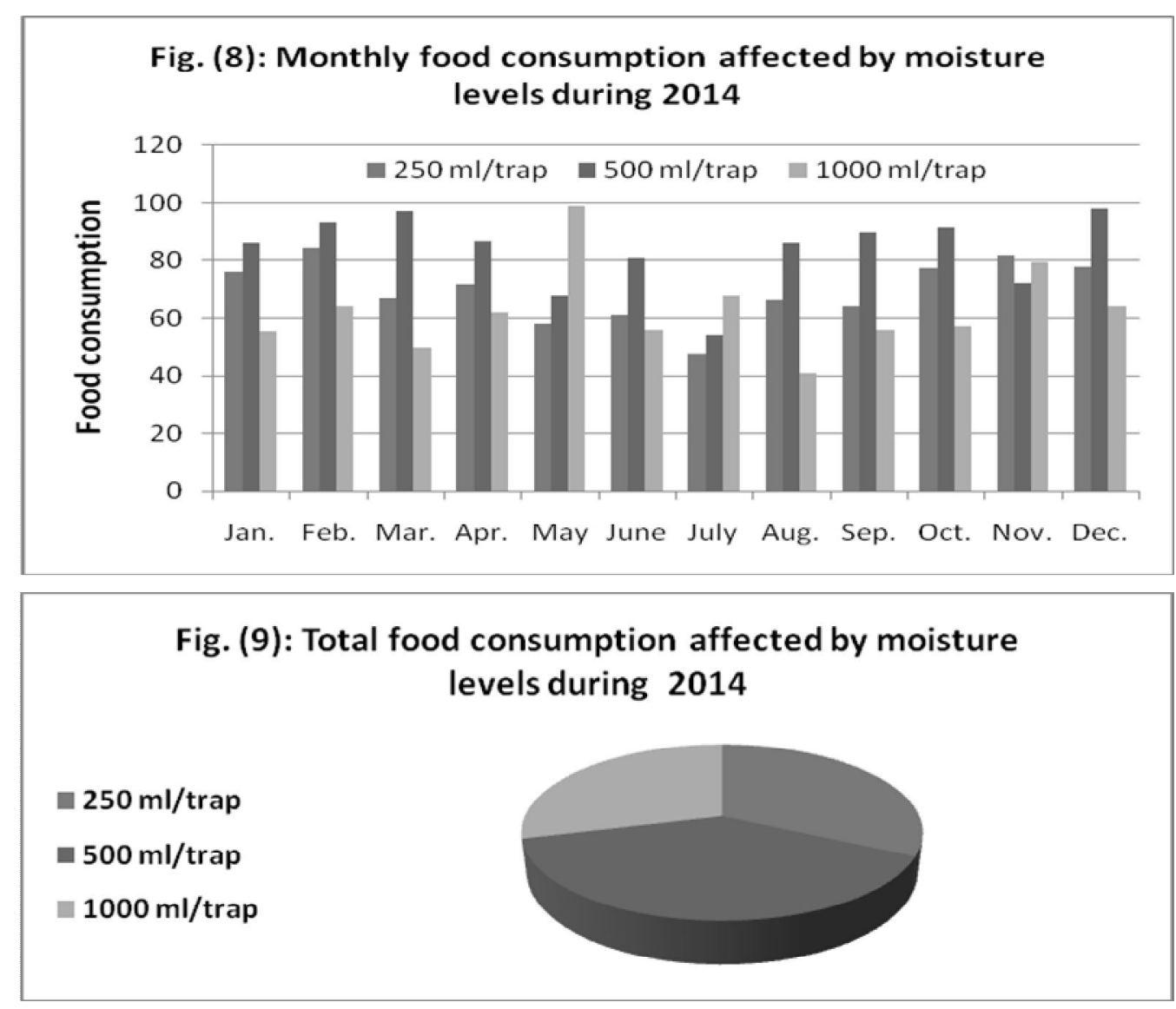

Bodot (1967), in tropical savanna, reported that rainfall increased foraging activity and vice versa in dry season. Among the factors that influence foraging were: soil temperature, relative humidity, rainfall, cast composition and nutrients, colony density, cast composition, and nutritional status of the colony. Harverty et al. (1975), in USA, studied the seasonal activity of the subterranean termites, Heterotermes areus (Snyder) and results that the foraging activity occurred throughout the year under a wide range of temperature, and reported that the foraging intensity was regulated according the fluctuation of the temperature and rainfall. La Fage et al. (1975), in USA, studied the climatic factors correlated with the foraging behaviour of a desert subterranean termite, Ganthomitermes perplexus (Bnks). They showed that forging activity was limited by upper level $(10-5 \mathrm{~cm})$ soil temperatures within the range $9-49^{\circ} \mathrm{C}$. Periodic rises in soil moisture resulting from rainfall increased foraging activity. Said (1979), stated that, traps attracted 37.3\% of Anacanthotermes ochraceus (Burm.), also the same auther added that, the quantity of soil translocated to each trap reached to minimum through mid-December, early-April and maximum level was observed through July-August and September. Khalifa (1982), mentioned that, the limiting factor for controlling termite activity was the moisture content in the 
soil. Termite activities result in various physical and chemical modifications in soil material. Movement of fine soil particles from the dense fine textured subsurface to the surface sands by the insect was evidenced by the relatively high content of silt clay in termite constructions. Abdel-Wahab et al. (1983), in Egypt, reported that the surface activity of Psammoterms hypostoma (Desn.) was determined by a bait technique. Data indicated that the wood consumption was at its minimal level in December 1981, but it increased gradually until April where the wood consumption reached its maximal level, then, the activity dropped again in May after that it increased gradually to reach a high level at August. El-Sebay (1991), in Egypt, designed a trap for subterranean termite, the trap facilitate ecological studies, it consists of corrugated card-board wrapped in a roll shape, $12 \mathrm{~cm}$ in length and 5-7 $\mathrm{cm}$, in diameter, covered with polyethylene sheets except $2 \mathrm{~cm}$ at the end position fixed with rubber band. The same auther in (1993), mentioned that, such traps were used for description three ecological aspects of subterranean termites, number of attracted termite, food consumption and soil translocation. El-Sebay (1993), in Egypt, estimated that the main activity of each soil translocation and food consumption of Anacanthotermes ochraceus (Burm.) during summer. The quantity of translocated soil ranged from 1878-6726 gm/colony/year and weight of food consumption from 1906$535 \mathrm{gm} /$ colony/year. Consumption rate of $A$. ochraceus was $7.6 \%$ of the successive vegetation covered the land/year and the rate of translocated soil was 2431 $\mathrm{kg} /$ feddan/year. Lys and Leuthold (1994), mentioned in a study where the only available food source was located on dry soil, that mortality of the subterranean termite Coptotermes formosanus Shiraki (Isoptera: Rhinotermitidae) was high, even though termites were able to travel freely between moist sand and dry soil. Clusters of desiccated termite bodies were observed on the surface of the dry soil in many of the replicates, possibly due to rapid desiccation caused by contact with dry soil, and there is an interaction between moisture availability and soil type. Both moisture retention and availability are affected by particle size. Water retention is higher in soils with smaller particles, but moisture availability is greater in soils with larger particles. Hence, termites are able to obtain of water from sandy soils with lower water content than clay soils. Ahmed (1997), in Egypt, stated that the maximum percentages of trap attraction were $50.0 \%$ in December and $46.0 \%$ in October. The minimum percentage of infestation was zero during June. Trap consumption reached its minimum level (1.0\%) during July and August, but it increased to $86.7 \%$ during December, while its maximum $13.3 \%$ during November and $30.0 \%$ in January. The percentage of traps 
with translocated soil reached its maximum during January, February, March 1994, and $50.0 \%$ during May and June 1995, while it reached minimum 33.3\% in November and $16.7 \%$ in September. The estimated weight of food consumption reached 36.9 $\mathrm{gm} / \mathrm{m}^{2}$ or $154.98 \mathrm{~kg} /$ feddan in 1994 , and $33.8 \mathrm{gm} / \mathrm{m}^{2}$ or $142.06 \mathrm{~kg} /$ feddan in 1995, the estimated weight of translocated soil reached $170 \mathrm{gm} / \mathrm{m}^{2}$ or $714 \mathrm{~kg} /$ feddan in 1994 and $131 \mathrm{gm} / \mathrm{m}^{2}$ or $551 \mathrm{~kg} /$ feddan in 1995. Grube and Rudolph (1999), mentioned that, termite activities in dry soils, termites need to relocate water molecules from moist soil into dry soil by using their salivary reservoirs as water sacs, these results are consistent with Gallagher and Jones, (2010). El-Bassiouny (2001), reported that, the highest monthly number of termites for all traps (surface activity) were occurred at December and January throughout the two seasons of 1995 and 1996, resp., while the monthly catching were the low during June in the two years, the subsurface activity (food consumption and soil translocation) were increased during summer and autumn, while it decreased during winter and spring in both years 1995 and 1996. Evans (2003); Studied the influence of moisture content on the subterranean termite feeding behavior, they found that termites need moist soil for their field activities, these results are agreement with Su \& Puche (2003); Green et al. (2005); Mc Manamy et al. (2008) and Gautam \& Henderson (2011a, 2011b). Cornelius and Osbrink (2010), stated that, moisture availability affected C. formosanus preferences for different soil types, when soils were moist, termites were significantly more likely to aggregate in topsoil than in potting soil or peat moss. In moist soils, termites aggregated in the soil with the smallest particle size and the least organic matter. When soils were dry, termites were significantly more likely to move into the soils containing the largest amount of organic matter, peat moss and potting soil, than into the soils with the least amount of organic matter, sand and clay.

\section{Conclusion and Statistical Analysis:}

The obtained data reveal that using El-Sebay-modified trap soaked in $500 \mathrm{ml}$ water/trap consider more appropriate to give the highest behavioral field activities of sand termite, P. hybostoma (Desn.) in light sandy soil which is characterized by fast leachibility. In second rank, using the rate of $250 \mathrm{ml}$ water/trap, but using rate of $1000 \mathrm{ml}$ water/trap caused the least activity. Unfortunately when using $1000 \mathrm{ml}$ water/trap, caused ratting and blockage of the trap inside and be unattractive to the insect. Data obtained in statistical analysis were not significant correlation at levels $250 \mathrm{ml}, 500 \mathrm{ml}$ and $1000 \mathrm{ml}$ water/trap. 


\section{REFERENCES}

1. Abdel-Wahab, A.M.; M.R. Rizk; M.H. Hussin; T.K. Abd El-Raof and M.S. El-Taib. 1983. Surface activity of sand termites Psammotermes hybostoma Desneux in Aswan. Assuit J. Agric. Sci., 14(3): 99-108.

2. Abou-Ghadir, M.F. and M.E. Khalifa. 1982. Desert termite and foraging populations and their relation to superficial wood and soil. Assuit J. Agric. Sci., 13 (3): 79-86.

3. Ahmed, H.M. 1997. Ecological control studies on subterranean termite, Anacanthotermes ochraceus (Burm.), at Fayoum Gov. M.Sc. thesis, Cairo University, Fayoum. pp 77.

4. Bodin, M.C. 1975. Effect of desert termites on herage and litter in a shortgrass ecosystem in west Texas. H. Damage Manage, 28: 353-358.

5. Bodot, P. 1967. Cycles soissnoiers d'activite collective des. Termites des savanes, de Basse cared'Ivoire. Insects Socioux, 14: 359-388.

6. Cornelius, M.L. and W.L.A. Osbrink. 2010. Effect of soil type and moisture availability on the foraging behavior of the Formosan subterranean termite (Isoptera: Rhinotermitidae). J. Econ., Entomol. 103: 799-807.

7. El-Bassiouny A.R; M.K. Abbas; N.N. Abdel-Malak and A.A. Mosa. 2009. Study on the effect of soil type on subterranean termite distribution with special reference to the soil properties occurred to termite activity. Egypt J. App. Sci., 24 (10B): 661-670

8. El-Bassiouny, A.R. 2001. A study on the ecology and biological control of subterranean termites, M.Sc. Thesis, Fac. Agric., Al-Azhar Univ. 145 p.

9. El-Sebay, Y. 1991. A modified trap for El-Sebay subterranean termites. Fourth Arab Cong. of Plant Protection, Cairo, 1-5 Dec. 1991.

10. El-Sebay, Y. 1993. Ecological studies on the colony of the harvester termite, $A$. ochraceus (Burm.) in Egypt. Bull. Soc. Ent. Egypt, Econ. Ser., 20: 1-9.

11. Evans, T.A. 2003. The influence of soil heterogeneity on exploratory tunneling by the subterranean termite Coptotermes frenchi (Isoptera: Rhinotermitidae). Bull. Entomol. Res., 93: 413-423.

12. Gallagher, N.T. and S.C. Jones. 2010. Moisture augmentation of food items by Reticulitermes flavipes (Isoptera: Rhinotermitidae). Sociobiol. 55: 735-747.

13. Gautam, B.K. and G. Henderson. 2011a. Effects of sand moisture level on food consumption and distribution of Formosan subterranean termites (Isoptera: Rhinotermitidae) with different soldier proportions. J. Entomol. Sci. 46: 1-13.

14. Gautam, B.K. and G. Henderson. 2011b. Wood consumption by Formosan subterranean termites (Isoptera: Rhinotermitidae) as affected by wood moisture content and temperature. Ann. Entomol. Soci. of America, 104: 459-464. 
15. Green, J.M; M.E. Scharf and G.W. Bennett. 2005. Impacts of soil moisture level on consumption and movement of three sympatric subterranean termites (Isoptera: Rhinotermitidae) in a laboratory assay. J. Econ. Entomol. 98: 933-937.

16. Grube, S. and D. Rudolph. 1999. Water supply during building activities in the subterranean termite Reticulitermes santonensis de Fey taud (Isoptera, Rhinotermitidae). Insects Sociaux, 46: 192-193.

17. Harverty, M. I.; J. P. Lafag and W. L. Nutting. 1975. Seasonal activity and environmental control of foraging of the subterranean termites, Heterotermes aureus (Snyder). Environ. Entomol. 4: 105-109.

18. Khalifa, E.M. 1982. Desert termite activities in relation with soil activities and characteristics. Assuit J. Agric. Sci., 13 (3): 55-71.

19. Lafage, J. P.; M. I. Harverty and W. L. Nutting. 1975. Environmental factors correlated with the foraging behavior of the desert subterranean termite, Ganthomitemes perplexur (Banks) (Isoptera: Lemrmitidae). Sociobiol. 2(3): 155-167.

20. Lys, J.A. and R. Leuthold. 1994. Forces affecting water imbibitions in Macrotermes workers (Termitidae: Isoptera). Insects Sociaux 41: 79-84.

21. McManamy, K.; P.G. Koehler; D.D. Branscome and R.M. Pereira. 2008. Wood moisture content affects the survival of Eastern subterranean termites (Isoptera: Rhinotermitidae), under saturated relative humidity conditions. Sociobiol. 52: 145-156.

22. Morsy, M.M.; M.M. Rizk and F.M. Khalil. 1982. Effect of Thermo Rhythm on termite food consumption. Assiut J. Agric. Sci., 13 (3): 43-50.

23. Rizk, M.M.A.; A.K. El-Sayed; A.M. Ali and S.A. Eraky. 1985. Flight activity and annual cost fluctuation and sand termite Psammotermes hybostoma Desenex, western Desert, Egypt. Assiut J. Agric. Sci., 16 (2): 137-148.

24. Said, W.A. 1979. Ecological and toxicological studies on Fam. Hodotermitidae. M. Sc. Thesis, Fac. of Agric., Ain-Shams Univ., Egypt.

25. Salman, A.G.A.; M.A.A. Morsy and A.A. Sayed. 1987. Foraging activity of the sand termite, Psammotermes hybostoma Desn. In the New Valley. Egypt. Assuit J. Agric. Sci., 18 (4): 51-57.

26. SAS Institute. 1988. SAS user's guide: Statistics. SAS Institute, Cary, N.C.

27. Su, N.Y. and H. Puche. 2003. Tunneling activity of subterranean termites (Isoptera: Rhinotermitidae) in sand with moisture gradients. J. Econ. Entomol. 96: 88-93. 
دراسة حقلية لتأثير كمية الرطوبة المضافة لمصيدة السباعى فى الأرض الرملية على الرى الرئ

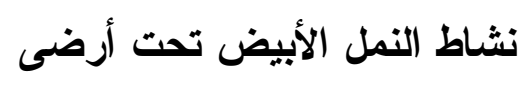

أيمن رمضان البسيونى

$$
\text { معهد بحوث وقاية النباتات - الدقي - الجيزة }
$$

تم إجراء التجربة فى أرض صحراوية ذات تربة رملية سلتية خفيفة بمنطقة الإسماعيلية

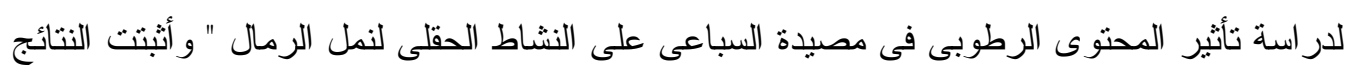

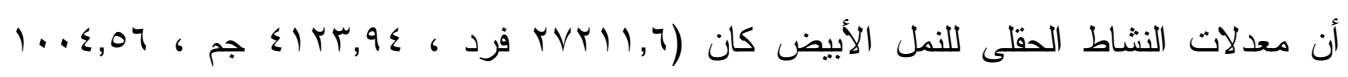

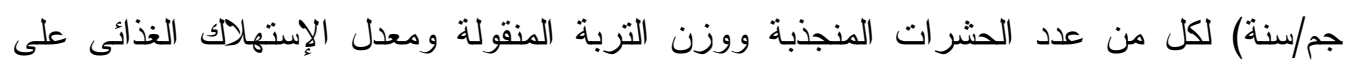

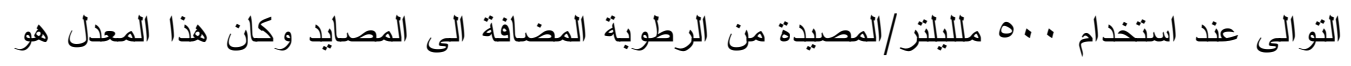

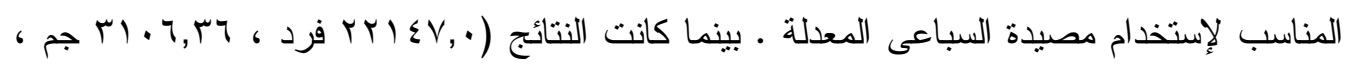

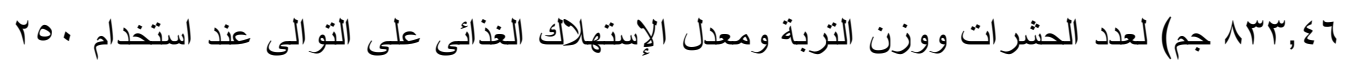

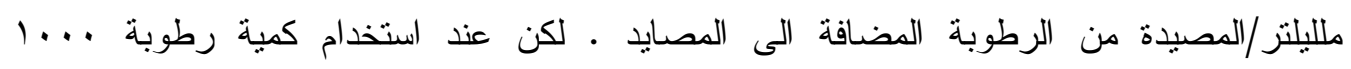

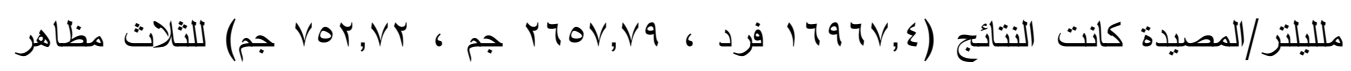

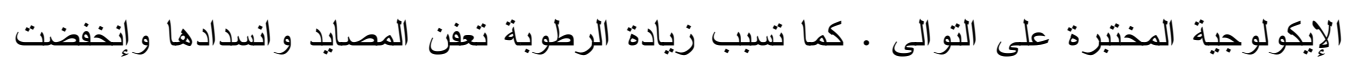

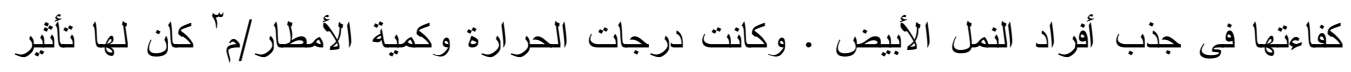

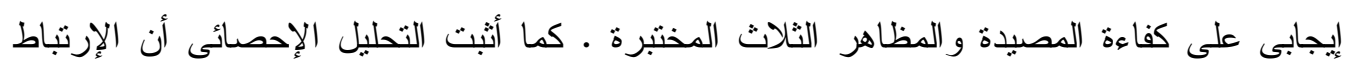

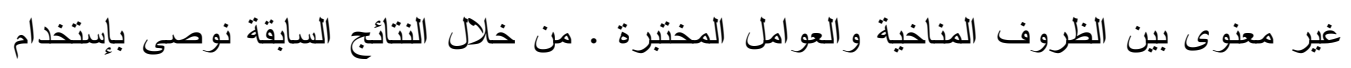
كمية الرطوبة ..0 ملليلتر/المصيدة عند استخدام مصيدة السباعى الكرتونية فى الأراضى الرملية 